\section{Long-Term Follow-up Results of Children Undergoing Achalasia Surgery}

\section{Akalazya Nedeniyle Ameliyat Edilen Çocukların Uzun Dönem Sonuçları}

\section{Kutay Bahadır $\odot$ Ergun Ergun $\odot$ Anar Jafarov $\odot$ Merve Bülbül $\odot$ Gülnur Göllü ๑ Meltem Bingöl-Koloğlu ๑ Aydın Yağmurlu $\odot$ Murat Çakmak $\odot$ Ufuk Ateş $\odot$}

\section{ABSTRACT}

Objective: Achalasia is a disease characterized by lower esophageal sphincter motility disorder. Whereas there is no clear algorithm in treating achalasia in children, Heller myotomy is known to be as the most effective method. Gastroesophageal reflux after myotomy is a frequently reported complication. Therefore, the fundoplication procedure should be added to the myotomy simultaneously. Our study aimed to present the results of patients who underwent Heller myotomy and fundoplication for achalasia.

Materails and Methods: Twelve patients who underwent laparoscopic Heller myotomy with the diagnosis of achalasia between the 2006 and 2019 have been included in the study.

Results: There were 12 children. $75 \%$ of them were male, and $25 \%$ were female. Laparoscopic Heller myotomy and antireflux procedure were applied to all patients. The average nasogastric withdrawal time was 1.75 days, the average time to start feeding was 2.25 days. The average hospital stay was 6.75 days. Dysphagia persisted in 3 patients who underwent Dor fundoplication and in 1 patient who underwent Toupet fundoplication at postoperative 3rd-week controls. It was observed that the symptoms improved after the one-time endoscopic dilatation procedure.

Conclusion: Heller myotomy is gold standard method in the treatment of achalasia in children. We believe that partial fundoplication added to myotomy reduces the risk of GER.

Keywords: Esophageal achalasia, heller myotomy, fundoplication

Öz

Amaç: Akalazya, alt özofagus sfinkterinde motilite bozukluğuyla karaterize bir hastalıktır. Çocuklarda akalazya tedavisinde net bir algoritma olamamakla birlikte Heller miyotomisi en etkili yöntem olarak kabul edilmektedir. Miyotomi sonrası gastroözofageal reflü sık bildirilen bir komplikasyondur. Bu nedenle miyotomiye eş zamanlı olarak fundoplikasyon prosedürü eklenebilir. Çalışmamızda akalazya nedeniyle Heller myotomi ve fundoplikasyon yapılan hastaların sonuçlarının sunulması amaçlanmıştır.

Yöntem: Kliniğimizde 2006-2019 yılları arasında akalazya tanısı ile laparoskopik Heller miyotomisi uygulanan 12 hasta çalışmaya dahil edildi.

Bulgular: Olguların \%75'i erkek, \%25'i kızdı. Hastalara laparoskopik Heller miyotomisi ve antireflü prosedürü uygulandı. Ortalama nazogastrik çekilme süresi 1,75 gün, ortalama beslenmeye başlama zamanı 2,25 gündü. Ortalama hastane yatış süresi 6,75 gündü. Dor fundoplikasyonu uygulanan 3 hastada ve Toupet fundoplikasyonu uygulanan 1 hastada postoperatif 3. hafta kontrollerinde disfajinin devam ettiği görüldü. Tek seferlik endoskopik dilatasyon işlemi sonrası semptomların düzeldiği izlendi. Sonuç: Heller miyotomi çocuklarda akalazya tedavisinde altın standart yöntemdir. Miyotomiye eklenen parsiyel fundoplikasyonun GÖR riskini azalttığını düşünüyoruz.

Anahtar kelimeler: Özofageal akalazya, heller miyotomi, fundoplikasyon
Received: 08.03 .2021

Accepted: 31.05 .2021

First Publication: 20.09.2021

Cite as: Bahadır K, Ergun E, Jafarov A, et al. Longterm follow-up results of children undergoing achalasia surgery. İzmir Dr. Behçet Uz Çocuk Hast. Dergisi. 2021;11(3):309-13.

Ufuk Ateş

Ankara Üniversitesi Tıp Fakültesi, Çocuk Cerrahisi Anabilim Dalı, Ankara, Türkiye drufukates@gmail.com ORCID: 0000-0001-6591-7168

K. Bahadır 0000-0002-4492-5262 Kırıkkale Yüksek ihtisas Devlet Hastanesi Çocuk Cerrahisi Anabilim Dalı, Kırıkkale, Türkiye

E. Ergun 0000-0001-8806-4022 A. Jafarov 0000-0003-0088-8209

M. Bülbül 0000-0003-1541-0670

G. Göllü 0000-0001-8163-2226

M. Bingöl-Koloğlu 0000-0001-7726-7633

A. Yağmurlu 0000-0002-3294-4482

M. Çakmak 0000-0002-4870-8361

Ankara Üniversitesi Tıp Fakültesi, Çocuk Cerrahisi Anabilim Dalı, Ankara, Türkiye 


\section{INTRODUCTION}

Achalasia is a pathology characterized by degeneration of myenteric neurons that innervate the lower end of the esophagus and characterized by a motility disorder in the esophagus ${ }^{(1,2)}$. It is a rare disease in children and its annual incidence is $0.11 / 100,000^{(2,3)}$. Although its etiology is not fully elucidated, it is thought to be autoimmunemediatedsituation connected with viral infections ${ }^{(4)}$. It has also been shown to be associated with trisomy 21 and Triple-A Syndrome (Achalasia, Alachymia, and Adrenal Insufficiency) ${ }^{(4,5)}$. Vomiting, loss of appetite and chronic cough may be the initial symptoms in children under five years of age, and it progressive dysphagia, regurgitation, chest pain, and growth retardation in older children ${ }^{(2,3,5)}$. The diagnosis may usually be made clinically. However, since the symptoms are generally interpreted in favor of gastroesophageal reflux (GER) due to its rarity, diagnosis is often delayed ${ }^{(4)}$. The definitive diagnosis is made by esophageal manometry, contrast studies and endoscopic examinations ${ }^{(3)}$.

The treatment of achalasia aims to relieve the symptoms by eliminating the obstruction in the lower esophageal sphincter with relaxation disorder ${ }^{(5)}$. For this purpose, pharmacological treatment such as calcium channel blocker and botulinum toxin injection, mechanical or pneumatic dilatation, open or laparoscopic esophagomyotomy (Heller Myotomy) can be used in treatment ${ }^{(4-6)}$. Pharmacological treatment options are not preferred in the pediatric population because of their short-term effectiveness, and calcium channel blockers have side effects such as headache and dizziness ${ }^{(4)}$. Although publications are reporting that pneumatic balloon dilatation is as effective as Heller myotomy in adult achalasia patients, it is not recommended for use in children because it is not designed for pediatric use ${ }^{(7)}$. Heller myotomy is considered as the most effective method in the treatment of achalasia ${ }^{(4,6)}$. GER is a frequently reported complication after Heller myotomy. Therefore, the fundoplication procedure is usually added to this Heller myotomy ${ }^{(4)}$.

Our study aimed to present the results of patients who underwent laparoscopic Heller myotomy and fundoplication due to achalasia.

\section{MATERIAL and METHODS}

Twelve patients with a diagnosis of achalasia who underwent laparoscopic Heller myotomy between 2006 and 2019 were included in the study. This study was conducted in accordance with the Helsinki Declaration and with the permission of the local ethics committee (No: 111-682-20) Demographic data, symptoms at the time of application, methods used in diagnosis, operation details (antireflux surgery added to myotomy, intraoperative complications), length of hospital stay, surgery complications, recurrence and follow-up results were reviewed retrospectively.

\section{Preoperative Management}

Patients who presented with a pre-diagnosis of achalasia were diagnosed by preoperative contrast studies and endoscopy (Figure 1). With the induction of anesthesia, a nasogastric catheter with a size suitable for the patient's age was inserted, and prophylaxis at a dose of $100 \mathrm{mg} / \mathrm{kg} /$ day of ceftriaxone was administered.

\section{Surgical Technique}

The patients were placed in a supine position under general anesthesia and prepared for the laparoscopic approach. A $5 \mathrm{~mm}$ (millimeter) camera trocar was inserted through the umbilicus and intraabdominal space was inflated with carbon dioxide up to $10-14 \mathrm{mmHg}$ according to the age of the patient. $5 \mathrm{~mm}$ working trocars were inserted from the right and left hypochondriac region from the $3 \mathrm{~cm}$ superolateral of the umbilicus under camera guidance. A $5 \mathrm{~mm}$ incision was made for liver retraction in the epigastric region, and a Nathanson retractor was inserted. The adequate vision was provided by retracting the liver. In esophageal dissection, only the anterior surface was dissected, preserving the posterior and lateral physiological adhesions. Appropriate abdominal esophagus was obtained and myotomy was performed from the 
gastroesophageal junction towards the distal esophagus. Myotomy was completed by cutting the muscle tissue up to the mucosa with the help of hook cautery. Saline was given to the area where myotomy was performed. At the same time, possible perforation controls were made by blowing air through a nasogastric catheter. Afterward, according to the surgeon's preference, an anti-reflux procedure was performed with Dor (Anterior partial fundoplication) or Toupet (Posterior partial fundoplication). Dor fundoplication is performed by wrapping the stomach 180 degrees around the anterior of esophagus. If Toupet procedure is performed, short gastric vessels are divided minimmaly, posterior part of the esophagus is dissected for fundus mobilization and fundus is wrapped 270 degrees around the posterior part of the esophagus. The procedure was completed by suturing the port incisions.

\section{Postoperative Management}

Generally, the patients' nasogastric catheters were removed on the first postoperative day, and oral fluid intake was allowed on the second day. Patients were recommended to feed a soft food diet for three weeks. Children were recommended to have outpatient visits at postoperative $3^{\text {rd }}$ week, $6^{\text {th }}$ and $24^{\text {th }}$ months. Gastrointestinal tract contraswt studies and/or esophagoscopy was performed in case of residual symptoms.

\section{RESULTS}

Between 2006-2019, 12 patients underwent surgery due to lower esophageal achalasia. Nine $(75 \%)$ of the patients were male, and $3(25 \%)$ were female. The median age of the patients was 12 years (1-17 years). Triple-A syndrome was found in 1 patient. All patients applied with symptoms of dysphagia. Additionally, 3 patients had vomiting, and 2 patients had retrosternal painsymptoms. Endoscopic balloon dilatation was performed initiallyfor 4 children in different centers. Laparoscopic Heller myotomy and antireflux surgery were performed in all of the patients. Dor fundoplication was performed in 4 patients and Toupet fundoplication in 8. There were no intraoperative complications. The average nasogastric withdrawal time was 1.75 days (1-3 days). The average feeding start time was 2.25 days ( $2-5$ days). The average hospital stay was 6.75 (3-19 days) days. The average follow-up time was 6.25 years (1-14 years). It was observed that dysphagia symptoms persisted in the postoperative $3^{\text {rd }}$-week control in 3 patients who underwent Dor partial fundoplication and in 1 patient who underwent Toupet partial fundoplication. The children underwent one time endoscopic dilatation and did not have any further symptoms.

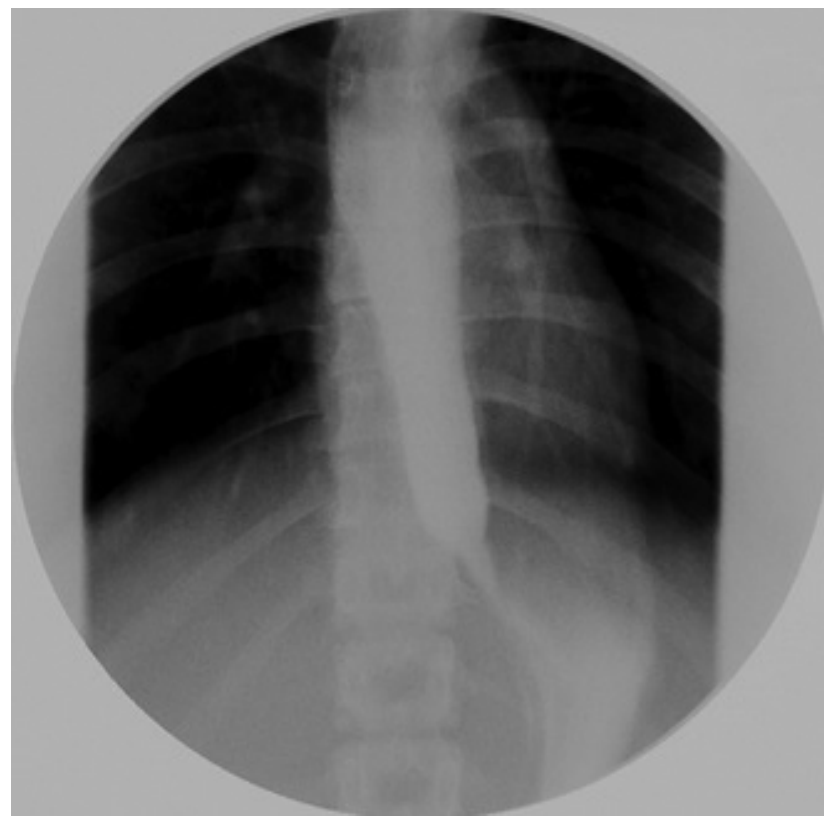

Figure 1. Preoperative esophageal stomach image taken for the diagnosis of achalasia.

\section{DISCUSSION}

Achalasia is an esophageal motility disorder that results in the inability to relax and peristalsis in the lower esophagus sphincter due to the pathology in the inhibitory ganglion cells in the myenteric plexus $(8,9)$. The study aims to show the results of patients who underwent Heller myotomy and antireflux surgery due to achalasia.

There are options such as calcium channel blockers such as nifedipine, botulinum toxin injection, endoscopic balloon dilatation, and surgical myotomy 
in the treatment of achalasia ${ }^{(3,5,6)}$. Although there is no consensus about which is the gold standard treatment, the treatment option with the highest success rate is Heller myotomy ${ }^{(8,9)}$. The short duration of calcium channel blocker and botulinum toxin injection effectiveness is seen as a disadvantage of pharmacological treatment $(4,10,11)$. In addition, although the short-term success rate in the treatment of achalasia is high, there are not enough studies in the literature regarding the optimal dose of botulinum toxin injection in pediatric patients ${ }^{(8)}$. Calcium channel blockers are not preferred in pediatric patients in the treatment of achalasia due to their side effects such as headache and dizziness ${ }^{(4)}$.

Although successful results have been published for endoscopic balloon dilatation used in adult series treatment, there are not enough publications about the success rate in pediatric patients ${ }^{(11)}$. Besides, it is not recommended to be used for treatment purposes in children under 5 years of age because of the technical difficulties ${ }^{(7,11)}$. Surgical myotomy becomes a priority in the treatment of pediatric patients due to complications such as recurrence of symptoms within the first year after balloon dilatation and the risk of perforation at a rate of $4-12 \%{ }^{(9,11,12)}$. In the first 4 patients in our series, endoscopic dilatation was applied primarily as a treatment. The recurrence of the patients' symptoms after the treatment led to myotomy as the first choice of treatment. Also, laparoscopic Heller myotomy is the preferred method in achalasia surgery because it gives early nutrition opportunity, the advantage of less analgesic need, it shortens the length of hospital stay, has better cosmetic results and shorter return to normal life ${ }^{(13)}$.

GER is a common complication after Heller myotomy in patients with achalasia. In the literature while some authors argue that an antireflux surgery should generally be added to the Heller myotomy to prevent this complication, some authors argue that dysphagia will recur, and therefore antireflux surgery should not be added $(4,8,14,15)$. The antireflux surgery procedure was performed simultaneously with myotomy in the present study. Dysphagia presented in four patients, and it resolved with endoscopic balloon dilatation in one session. There were not postoperative GER findings in any patient. A partial antireflux procedure may respond these arguments since it may prevent reflux and also not cause dysphagia. Dor and Toupet fundoplications may both be performed but the authors' prefer Dor fundoplication in case of intraoperative esophageal perforations since it may prevent esophageal leakage. This suggestion may only be hypothetical since we did not encounter any esophageal perforations in our series.

Another controversial issue is that which fundoplication procedure will be added to Heller myotomy simultaneously ${ }^{(14)}$. Considering the literature, the most preferred surgical procedure has been reported as $360^{\circ}$ total Nissen fundoplication, $270^{\circ}$ Toupet posterior partial fundoplication, and $180^{\circ}$ Dor anterior partial fundoplication ${ }^{(14)}$. Some authors argue that the presence of motility impairment and total Nissen fundoplication in achalasia patients will increase esophageal emptying more than partial fundoplications. Therefore, there will be a symptom of permanent dysphagia ${ }^{(14)}$. In their 10-year series published by Topart et al., it was reported that there were $82 \%$ recurrent dysphagia (16). In the 5-year series published by Rebecchi et al., it was reported that the recurrent dysphagia symptom was higher in patients who underwent Nissen total fundoplication compared to patients who underwent Dor anterior partial fundoplication ${ }^{(17)}$. The advantages of toupet posterior partial fundoplication and Dor anterior partial fundoplication over each other have not been demonstrated in the literature ${ }^{(14)}$. Therefore, we think that surgeons should choose one of these procedures according to their experience and preference.

The study's limitation is that the two groups that underwent partial fundoplication were not statistically compared because of the small number of patients.

Heller myotomy is gold standard method in the treatment of achalasia in children. Partial fundoplication added to myotomy may reduce the risk of GER and dysphagia. 
Ethics Committee Approval: Ankara University Ethics Committee approval was obtained (24.12.2020/682-

20).

Conflict of Interest: The authors report no proprietary or commercial interest in any product mentioned or concept discussed in this article.

Funding: None.

Informed Consent: Informed consent was obtained from the patients family with regards they could be used in the scientific study before the operation.

\section{REFERENCES}

1. Bloomston M, Boyce W, Mamel J, Albrink M, Murr M, Durkin A, Rosemurgy A. Videoscopic Heller myotomy for achalasia - Results beyond short-term follow-up. J Surg Res. 2000;92(2):150-6. https://doi.org/10.1006/jsre.2000.5886

2. Lee CW, Kays DW, Chen MK, Islam S. Outcomes of treatment of childhood achalasia. J Pediatr Surg. 2010;332(4):927-32. https://doi.org/10.1016/j.jpedsurg.2010.02.086

3. Franklin AL. Childhood achalasia: A comprehensive review of disease, diagnosis and therapeutic management. World J Gastrointest Endosc. 2014;6(4):105. https://doi.org/10.4253/wjge.v6.i4.105

4. van Lennep $M$, van Wijk MP, Omari TIM, Benninga MA, Singendonk MMJ. Clinical management of pediatric achalasia. Expert Rev of Gastroenterol and Hepatol. 2018;12(4):391404.

https://doi.org/10.1080/17474124.2018.1441023. Epub 2018 Feb 26.

5. Meyer A, Catto-Smith A, Crameri J, Simpson D, Alex G, Hardikar W, Cameron D, Oliver M. Achalasia: Outcome in children. J Gastroenterol Hepatol. 2017;32(2):395-400. https://doi.org/10.1111/jgh.13484

6. Litle VR. Laparoscopic Heller Myotomy for Achalasia: A Review of the Controversies. Ann Thorac Surg. 2008;85(2):743-6. https://doi.org/10.1016/j.athoracsur.2007.12.004

7. Nabi Z, Ramchandani M, Chavan R, Darisetty S, Kalapala R, Shava U, Tandan M, Kotla R, Reddy N. Outcome of peroral endoscopic myotomy in children with achalasia. Surg Endosc. 2019;33(11):3656-64. https://doi.org/10.1007/s00464-018-06654-1. Epub 2019 Jan 22.

8. Divarci E. Esophageal Functional Disorders in Children.
Turkiye Klin J Pediatr Surg-Special Top. 2015;5(2):47-53. Avaible From: https://www.researchgate.net/ publication/281632867_Cocuklarda_Ozofagus_Fonksiyon_ Bozukluklari

9. Imperiale TF, O'Connor JB, Vaezi MF, Richter JE. A costminimization analysis of alternative treatment strategies for achalasia. Am J Gastroenterol. 2000;95(10):2737-45.

https://doi.org/10.1111/j.1572-0241.2000.03181.x

10. Guvenc H, Avtan L, Ekingen G, Sozubir S, Günaltay N, Senel U. Laparoscopic Heller Esophagomyotomy Without Fundoplicatin in Pediatric Achalasia Patients. End Lap ve Minimal İnvaziv Cerrahi Derg. 2002;9(3):171-4.

Avaible from: https://www.researchgate.net/ publication/290169161_Laparoscopic_Heller_ esophagomyotomy_in_pediatric_achalasia_disease

11. Di Nardo G, Rossi P, Oliva S, Aloi M, Cozzi D, Frediani S, Redler A, Mallardo S, Ferrari F, Cucchiara S. Pneumatic balloon dilation in pediatric achalasia: Efficacy and factors predicting outcome at a single tertiary pediatric gastroenterology center. Gastrointest Endosc. 2012;76(5):927-32. https://doi.org/10.1016/j.gie.2012.06.035. Epub 2012 Aug 21.

12. Zaheed Hussain $S$, Thomas $R$, Tolia V. A review of achalasia in 33 children. Dig Dis Sci. 2002;47(11):2538-43. https://doi.org/10.1023/A:1020572328777

13. Patti MG, Pellegrini CA, Horgan $S$, Arcerito $M$, Omelanczuk $P$, Tamburini A, Diener U, Eubanks TR, Way LW. Minimally invasive surgery for achalasia: An 8-year experience with 168 patients. Ann Surg. 1999;230(4):587-93. https://doi.org/10.1097/00000658-199910000-00014

14. Di Corpo M, Farrell TM, Patti MG. Laparoscopic Heller Myotomy: A Fundoplication Is Necessary to Control Gastroesophageal Reflux. J Laparoendosc Adv Surg Tech. 2019;29(6):721-5. https://doi.org/10.1089/lap.2019.0155. Epub 2019 Apr 19.

15. Diamantis T, Pikoulis E, Felekouras E. Tsigris C, Arvelakis A, Karavokyros I, Bastounis E. Laparoscopic esophagomyotomy for achalasia without a complementary antireflux procedure. J Laparoendosc Adv Surg Tech. 2006;16(4):345-9. https://doi.org/10.1089/lap.2006.16.345

16. Topart P, Deschamps C, Taillefer R, Duranceau A. Long-term effect of total fundoplication on the myotomized esophagus. Ann Thorac Surg. 1992;54(6):1046-51. https://doi.org/10.1016/0003-4975(92)90068-F

17. Rebecchi F, Giaccone C, Farinella E, Campaci R, Morino M. Randomized controlled trial of laparoscopic heller myotomy plus dor fundoplication versus nissen fundoplication for achalasia long-term results. Ann Surg. 2008; 248(6):102330. https://doi.org/10.1097/SLA.0b013e318190a776 